\title{
Comprehensive explorations of nutritional, functional and potential tasty components of various types of Sufu, a Chinese fermented soybean appetizer
}

\author{
Chunzhi XIE ${ }^{1}$, Haiying ZENG², Jinwei LI ${ }^{3}$, Likang QIN²,4*
}

\begin{abstract}
The nutritional, functional and tasty components of three categories of Sufu, divided by strains in the culture phase, were comprehensively investigated in this study. The levels of isoflavones, $\gamma$-aminobutyric acid (GABA), phytosterols and soyasaponin were $0.58-2.20,7.46-57.95,0.73-2.72$ and $10.89-23.35 \mathrm{mg} / \mathrm{g}$ dry matter (DM), respectively. Glu was the most abundant of the 17 detected free amino acids (FAAs), followed by Phe, Leu, Val and Asp. Additionally, potential tasty peptide profiles were typed by the segment of molecular weight $(\mathrm{MW})<300 \mathrm{Da}$, ranging from $79.22 \% \pm 4.12 \%$ to $95.24 \% \pm 2.93 \%$. The complex taste impression based on the electronic tongue showed that the bitterness intensity was the highest, which was followed by saltiness and the umami intensity. To some extent, different Sufu categories can be distinguished according to the electronic tongue. The results provide a theoretical basis for improving the quality control and standardization of the manufacturing process.
\end{abstract}

Keywords: Sufu; functional properties; free amino acid; peptide profile; taste.

Practical Application: Sufu is rich in nutritional and functional components and different sufu categories can be distinguished based on the electronic tongue.

\section{Introduction}

Sufu, douchi, soy sauce and bean sauce are known as four traditional fermented soybean appetizers in China. Thereinto, Sufu is a vegetal protein product that is superior to animal proteins and is called "Chinese cheese" because of its similarities to cheese in principle and production. Attributing to the pronounced nutritive value, delicious taste, distinctive flavor, rich variety and fine texture, Sufu has been widely consumed by the Chinese as an appetizer for centuries (Li et al., 2010). It has been estimated that the annual production of Sufu is over 300,000 tons in China alone and is becoming increasingly popular worldwide (Xia et al., 2014). Based on strains in the culture phase, Sufu is classified as three categories including mould-fermented Sufu (MFS), naturally-fermented Sufu (NFS) and bacteria-fermented Sufu (BFS). Generally, Sufu cubes are immersed in dressing mixtures and MFS is the predominant type in China. According to the color and flavor, Sufu can be classified into the following four categories: red Sufu, white Sufu, grey Sufu and other Sufus (Han et al., 2001a, b). Most Sufus are produced by a similar principle, which involves four main steps including preparation of tofu, preparation of pehtze, brine and ripening. The schematic diagram for production of sufu is shown in Figure 1.

Sufu is an easily digested, nutritious oriental fermented soybean food. During fermentation, soybean protein is hydrolyzed by microbes and converted into smaller nitrogen-containing compounds, such as low-molecular mass peptides, amino acids and ammonia, which have significant impacts on the characteristics of Sufu (Tang et al., 2011; Tsai et al., 2007). It contains various amino acids in a sufficient quantity and reasonable proportions. The patterns of essential amino acids (EAAs) are comparable to those of eggs and milk proteins (Han et al., 2004). Due to the cholesterol-free, Sufu can be used as a substitute for animal proteins and has an impact on preventing and treating chronic diseases, as supported by epidemiological studies (Jianming et al., 2013). Fermentation not only improves digestibility and bioavailability, but eliminates the flatulence component, beany flavor and bitter taste. As one of the functional components in Sufu, isoflavones are referred to as phytoestrogens due to their estrogenic activities in soybean and soybean foods, and the corresponding glucosides are converted into the corresponding aglycones through hydrolysis by $\beta$-glucosidase during fermentation. The distribution of isoflavone aglycones increased from $13.17 \%$ to $39.88 \%$ after 16 days of ripening, while the corresponding levels of glucosides decreased (Cheng et al., 2011). In addition, some other functional components, such as GABA, phytosterol and soyasaponin, are also enhanced during fermentation. Considerable attention has been paid to their health protective effects, including reducing the risk of cardiovascular disease (Lou et al., 2016), preventing cardiac injury and cancer (Kucuk, 2017), reducing blood pressure and lowering cholesterol (Cusack et al., 2013). Although these reports documented the nutritional and functional components w, most studies were only performed on red or white Sufu. 


\section{Preparation of tofu \\ (Soybean grinding, Soymilk Coagulation) \\ Preparation of pehtze}

(Inoculation with moulds, bacteria or natural inoculation )

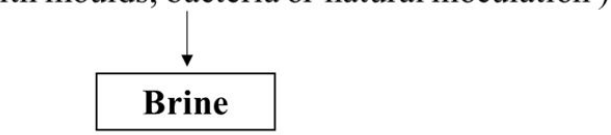

(Salt content 15\%-30\%)

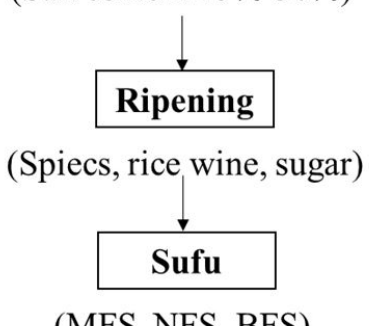

(MFS, NFS, BFS)

Figure 1. The schematic diagram for production of Sufu. BFS, NFS and MFS represented bacteria-fermented Sufu, naturally-fermented Sufu and mould-fermented Sufu, respectively.

The lack of comprehensive comparative analysis of different types of Sufu limits the overall recognition of nutritional and functional components.

The proteolytic tasty components, including free amino acids (FAAs) and low-molecular mass peptides, are derived from the degradation of crude protein during fermentation. These components play important roles in both the taste characteristics and nutritive value. For example, Glu can impart a savory, brothy, rich or meaty taste sensation and is considered to be one of the most important contributors to oriental fermented soybean products (Thammarongtham et al., 2001). Therefore, amino acids used in food processing can enhance the natural characteristic tastes and nutritive value of fermented foods. The addition of FAAs in the manufacture of dry-fermented sausages, as a method to enhance their flavor, has a beneficial effect on the flavor of the final product due to the high level of substrate for deamination, decarboxylation and transamination reactions (Herranz et al., 2005). In the analysis by Ishimoto et al. (2010), the use of Trp was demonstrated to be a reliable approach to improve the nutritional quality of soybean food. Fermentation and the ripening process led to the release of peptides, and greatly improving angiotensin I-converting enzyme inhibitory activity (Ma et al., 2014). Electronic tongue (E-tongue), which comprises an array of sensors with nonselective responses to a range of inorganic and organic substances, can gather global information including sensory data and analytical properties according to the basic gustatory attributes (Dong et al., 2017). As a powerful taste sensor device, E-tongue has been widely applied to distinguish complex taste impressions contributed by tasty components (Cetó et al., 2017; Kang et al., 2014; Marx et al., 2017). However, few reports on potential tasty components and complex taste impressions for Sufu are currently available.

The aim of this study was to comprehensively analyze the proximate compositions and functional components including isoflavones, GABA, phytosterols and soyasaponin in different Sufu varieties. More importantly, potential tasty components, such as FAAs and peptide profiles, and complex taste impressions were also investigated. The study will help people gain a deeper understanding of different categories of Chinese Sufu and improve its quality.

\section{Materials and methods}

\subsection{Sufu samples}

Three categories of Sufu containing bacteria-fermented Sufu (BFS), naturally-fermented Sufu (NFS) and mould-fermented Sufu (MFS), were purchased from various regions in China (Table 1). Six kinds of MFS with different color and flavor were randomly collected including red Sufu (RS), white Sufu (WS), grey Sufu (GS) and other types (jiang Sufu, JS; zaofang Sufu, ZS; cabbage Sufu, CS). KS and SS represented kedong Sufu and spontaneous Sufu, respectively. All of them were produced around the same date and represented Sufus from different production area.

\subsection{Chemicals and standards}

Daidzin, genistein, daidzein, GABA, $\beta$-sitosterol, stigmasterol, soyasaponin, amino acid standard solution and peptide standards (cytochrome c $12500 \mathrm{Da}$, aprotinin $6500 \mathrm{Da}$, bacitracin $1450 \mathrm{Da}$, glycocoll-glycocoll-tyrosine-arginine $451 \mathrm{Da}$, and glycocoll-glycocoll-glycocoll $189 \mathrm{Da}$ ) were purchased from Sigma-Aldrich Co. Ltd, USA. Acetonitrile, methanol, acetic acid, and trifluoroacetic acid were of high-performance liquid chromatography (HPLC) grade. All other chemicals were of analytical grade.

\subsection{Sampling}

The same quantities of Sufu cubes from five cans were rinsed and soaked in distilled water for $5 \mathrm{~min}$. Then, the water was removed using a filter screen. A surface of approximately $0.5 \mathrm{~cm}$ was removed to avoid the interference of dressing mixtures. Finally, the samples were freeze-dried in a freezer dryer instrument (FD-1A-50, Boyikang Ltd., Beijing, China), ground into powders, screened, sieved through a 60-mesh sieve and then preserved at $-20^{\circ} \mathrm{C}$ until analysis.

\subsection{Determination of proximate compositions and $\mathrm{pH}$}

The proximate compositions including moisture, fat, protein and salt were determined according to the Association of Official Analytical Chemists (2000).

The $\mathrm{pH}$ was determined by digital $\mathrm{pH}$ meter. Briefly, Sufu sample $(5 \mathrm{~g})$ was mixed with $50 \mathrm{~mL}$ of distilled water, homogenized and filtered. The digital $\mathrm{pH}$ meter (ZD-2A, Dapu Instrument, China) was calibrated using standard solutions with known $\mathrm{pH}$ 
Table 1. The details of different commercial Sufu varieties.

\begin{tabular}{|c|c|c|c|c|c|c|}
\hline Categories & Main constituents & Sample & Characteristic constituents & Production location & $\begin{array}{l}\text { Shelf-life } \\
\text { (months) }\end{array}$ & Production date \\
\hline $\mathrm{BFS}^{\mathrm{a} \#}$ & Northeast spring soybean & $\mathrm{KS}^{\mathrm{b} \#}$ & red kojic rice, white spirit, flour & $\begin{array}{l}\text { Heilongjiang } \\
\text { province }\end{array}$ & 12 & August, 2016 \\
\hline $\mathrm{NFS}^{\mathrm{a} *}$ & $\begin{array}{l}\text { Yun-Gui plateau summer } \\
\text { soybean }\end{array}$ & $S S^{b *}$ & white spirit, $\mathrm{MSG}^{\mathrm{c}}$, spices & Guizhou province & 12 & August, 2016 \\
\hline \multirow[t]{6}{*}{ MFS $^{a \star}$} & \multirow{6}{*}{$\begin{array}{l}\text { Huang-Huai plain and } \\
\text { Yangtze valley summer } \\
\text { soybean. }\end{array}$} & $\mathrm{WS}^{\mathrm{b} \star}$ & alcoholic beverage, MSG, spices, sugar & Beijing & 18 & August, 2016 \\
\hline & & $\mathrm{RS}^{\mathrm{b} \star}$ & red kojic rice, rice wine, sugar & Shanghai & 12 & August, 2016 \\
\hline & & $\mathrm{GS}^{\mathrm{b} \star}$ & pepper & Beijing & 12 & August, 2016 \\
\hline & & $J S^{b \star}$ & rice wine, sugar, glutinous rice, & Taiwan province & 24 & July, 2016 \\
\hline & & $\mathrm{ZS}^{\mathrm{b} \star}$ & sugar, glutinous rice, flour, mash & Jiangsu province & 12 & August, 2016 \\
\hline & & $\mathrm{CS}^{\mathrm{b} \star}$ & cabbage leaf, white spirit, spices & Sichuan province & 18 & August, 2016 \\
\hline
\end{tabular}

${ }^{a}$ BFS (bacteria-fermented Sufu); NFS (naturally-fermented Sufu); MFS (mould-fermented Sufu); ${ }^{\text {KKS }}$ (kedong Sufu) was categorized as BFS"; SS $^{*}$ (spontaneous Sufu) was categorized

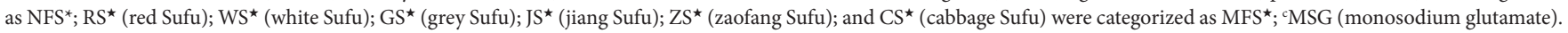

values (4.00, 6.86 and 9.18). The $\mathrm{pH}$ value of the sample solutions was directly read from the instrument.

\subsection{Determination of functional components}

The qualitative and quantitative analysis of the functional components including isoflavone, GABA, phytosterols and soyasaponin were performed by HPLC. The HPLC equipment (Agilent 1260, Agilent Ltd, USA) equipped with a Phecda $C_{18}$ column $(250 \times 4.6 \mathrm{~mm}, 5 \mu \mathrm{m})$. The compounds were identified by comparing the spectra and retention times of peaks detected in Sufus with those of reference standards. The retention times of standards isoflavone (daidzin $4.67 \mathrm{~min}$, daidzein $11.00 \mathrm{~min}$, genistein $15.38 \mathrm{~min}$ ), GABA (8.05 min), phytosterols (stigmasterol $7.69 \mathrm{~min}, \beta$-sitosterol $8.48 \mathrm{~min}$ ) and soyasaponin (13.18 $\mathrm{min}$ ) were determined, respectively. The representative chromatographic profiles for each analysis have been added in the supplementary material.

For isoflavone analysis, an ultraviolet spectrophotometer at a wavelength of $254 \mathrm{~nm}$ was used (Cai et al., 2016). The linear HPLC gradient consisted of (A) acetonitrile and (B) deionized water containing $1 \%$ acetic acid $(\mathrm{V} / \mathrm{V})$. After $20 \mu \mathrm{L}$ injection of sample into the column, solvent A increased from $30 \%$ to $50 \%$ within $15 \mathrm{~min}$ and then from $50 \%$ to $70 \%$ in another $5 \mathrm{~min}$, where it was held for the next $8 \mathrm{~min}$. Finally, solvent A decreased to $30 \%$ in $2 \mathrm{~min}$. The levels of isoflavones were calculated from standard curves of the area responses for isoflavone standards. For phytosterols analysis, the mobile phase was methanol containing $0.1 \%(\mathrm{v} / \mathrm{v})$ acetic acid. The solvent flow rate was $1.0 \mathrm{~mL} / \mathrm{min}$ and detection wavelength was $210 \mathrm{~nm}$. Quantitative data for $\beta$-sitosterol and stigmasterol were obtained by comparison with known standards. Soyasaponin was analyzed by evaporative light scattering detector. Acetonitrile, 1-propanol, deionized water and acetic acid (32.3: 4.2:63.4:0.1, v/v/v/v) were used as mobile phase. The solvent flow rate was $1.0 \mathrm{~mL} / \mathrm{min}$. GABA was measured at a wavelength of $254 \mathrm{~nm}$. The mobile phase consisted of methanol (A) and deionized water (B). Solvent A increased from $20 \%$ to $100 \%$ within $20 \mathrm{~min}$ and then held for the $15 \mathrm{~min}$. Finally, solvent A decreased to $20 \%$ in next 5 min (Liu et al., 2015).

\subsection{Determination of Free Amino Acid (FAA) profiles}

The concentrations of FAAs were determined according to the method utilized by Yoon et al. (2017). The FAAs were analyzed using an L-8800 amino acid analyzer (Hitachi Ltd., Japan). Calculation of the individual FAAs was performed according to the external standards. According to the taste characteristics, as described by Tseng et al. (2005), the FAAs were grouped as monosodium glutamate-like (MSG-like) (Asp + Glu), sweet (Ala + Gly + Ser + Thr), bitter $($ Arg + His + Ile + Leu + Met + Phe + Trp + Val $)$ and tasteless (Cys + Lys + Pro).

\subsection{Determination of peptide profiles}

The molecular mass distribution of the low-molecular mass peptides in water-soluble fraction (WSF) was determined by gel permeation high-performance liquid chromatography (GP-HPLC) according to the method described by Qin \& Ding (2007). Briefly, freeze-dried Sufu samples were dissolved in a 50\% acetonitrile solution containing $0.1 \%$ trifluoroacetic acid, then sonicated for $20 \mathrm{~min}$ and centrifuged for $15 \mathrm{~min}$ at $20000 \mathrm{rpm}$. Next, the supernatant was filtered through a $0.45-\mu \mathrm{m}$ filter and evaluated by GP-HPLC on a TSK gel 2000 SWXL column $(300 \times 7.8 \mathrm{~mm}, 5 \mu \mathrm{m})$. The mobile phase was acetonitrile/distilled water/trifluoroacetic acid (45:55:0.1, v/v/v). The solvent flow rate was $0.5 \mathrm{~mL} / \mathrm{min}$ and the detection wavelength was $220 \mathrm{~nm}$. The molecular weight distribution of water-soluble protein hydrolysates was obtained by comparison with known standards (cytochrome $12500 \mathrm{Da}$, aprotinin $6500 \mathrm{Da}$, bacitracin $1450 \mathrm{Da}$, glycocoll-glycocoll-tyrosine-arginine $451 \mathrm{Da}$, and glycocoll-glycocoll-glycocoll $189 \mathrm{Da}$ ). The peptide fractions were expressed as the percentage of the total area of the four segments combined.

\subsection{Electronic tongue analysis}

The taste characteristics of Sufus were measured using an electronic tongue (TS-5000Z, Intelligent Sensor Technology Co. Ltd., Japan). Prior to the measurement, $15 \mathrm{~g}$ of finely ground Sufu samples were suspended in $100 \mathrm{~mL}$ of distilled water for $30 \mathrm{~min}$. After filtration, $90 \mathrm{~mL}$ of test solution was used for further analysis. The electronic sensors were fabricated by the 
self-assembly technique using an automatic film deposition and dipped into reference solutions successively for $90 \mathrm{~s}, 120 \mathrm{~s}$ and $120 \mathrm{~s}$, respectively. After returning to zero at the equilibrium position for $30 \mathrm{~s}$, the sensors were immersed into sample solutions for $30 \mathrm{~s}$. Each sample was analyzed in sextuplicate, and the average values were used for the subsequent analysis.

\subsection{Statistical analysis}

The mean values and standard deviations were calculated from the data obtained from three separate experiments and data are expressed as the mean \pm standard deviation, where feasible. The statistical analysis was performed using SPSS 20.0 software. Significant differences were determined via an analysis of variance, and means in the same row with different letters are significantly different according to Duncan's multiple range test $(\mathrm{p}<0.05)$. Principal component analysis (PCA) was employed for the multivariate data analysis.

\section{Results and discussion}

\subsection{Proximate compositions and $\mathrm{pH}$}

To provide information for improvement of Sufu quality, the proximate compositions and $\mathrm{pH}$ were investigated (Table 2). The moisture contents, ranging from $25.04 \%$ to $43.46 \%$, were significantly different $(\mathrm{p}<0.05)$ among the various samples. The variation in the moisture content was probably due to the differences in the gel network within the particles, which was influenced by different anions and its ionic strengths towards the water holding capacity of protein gels (Wilcox et al., 2012). Protein and fat were the main components that affected the texture, taste and flavor. BFS (KS) and NFS (SS) mainly made from Northeast spring soybean and Yun-Gui plateau summer soybean respectively, while most NFS (WS, RS, GS, ZF and CS) mainly made from Huang-Huai plain and Yangtze valley summer soybean. The fat of Northeast spring soybean was highest, while the protein of Yungui plateau summer soybean was the highest due to the different climatic environment. The fat and protein contents in different Sufu varieties well explained the important impacts of soybean varieties. Except ZS, the salt content of MFS was higher than that in NFS (17.85 g/100 g DM) and BFS (16.71 g/100 g DM); also, it was higher than the results $(8.21 \%)$ reported by other scholars (Wilcox et al., 2012). Salt had multiple impacts on Sufu quality. It not only imparts a salty taste, but also influences biochemical changes and inhibit harmful micro-organism growth by controlling the enzyme activity. Salt in a dressing mixture of Sufu strongly affected the changes in textural properties, protein hydrolysis and lipid hydrolysis. Epidemiological studies have suggested that there is a positive correlation between dietary salt intake and blood pressure. However, whether salt in fermented soybean foods causes health problems remains controversial. A study was conducted to compare the effects of miso and $\mathrm{NaCl}$ on blood pressure. The results suggested that miso might prevent increased blood pressure in both epidemiology and animal experiments (Watanabe et al., 2006). The weak acidity ranged from $\mathrm{pH} 5.11$ to $\mathrm{pH} 6.46$. Autolysis of microbial cells, accumulation of free fatty acids, amino acids and peptides containing carboxylic side chains as a result of hydrolysis of tofu constituents, and the microbial fermentation during the ripening period may have contributed to the phenomenon. Taking lactobacillus for instance, other than lactic acid, some lactobacillus transformed the carbohydrates into acetic acid, which contributed to the acidity (Gomaa \& Rushdy, 2014).

\subsection{Major functional components}

The functional components, including isoflavones, GABA, phytosterols and soyasaponin, are shown in Figure 2. Isoflavones occur in the form of aglycones (daidzein and genistein) and corresponding glucosidic conjugates (daidzin). The total isoflavones ranged from $0.58 \mathrm{mg} / 100 \mathrm{~g} \mathrm{DM}$ to $2.20 \mathrm{mg} / 100 \mathrm{~g} \mathrm{DM}$ in the investigated Sufus, which were much lower than in tofu (70 mg/100 g) (Liu et al., 2005). The possible reasons were that processing including soaking, grinding and salting, could lose many isoflavones due to the conversion of glucosides to aglycones and other chemical compounds. However, the bioconversion of isoflavones from glucosides to aglycones may strongly enhance the functional properties of Sufu (Cai et al., 2016; Cheng et al., 2013). Daidzin and genistein were higher than daidzein in most Sufus, and they were predominantly in the form of aglycones. WS was characterized for having the highest levels of daidzin

Table 2. Proximate compositions and $\mathrm{pH}$ of different Sufu varieties ${ }^{\mathrm{a}, \mathrm{b}}$.

\begin{tabular}{|c|c|c|c|c|c|}
\hline Samples & Moisture(\%) & Fat(g / 100 g DM $)$ & $\operatorname{Protein}(\mathrm{g} / 100 \mathrm{~g}$ DM $)$ & Salt(g /100 g DM) & $\mathrm{pH}$ \\
\hline $\mathrm{KS}^{\mathrm{c}}$ & $43.46 \pm 0.88 \mathrm{a}$ & $23.66 \pm 0.70 \mathrm{~d}$ & $33.13 \pm 0.21 \mathrm{~b}$ & $32.40 \pm 0.37 \mathrm{e}$ & $5.65 \pm 0.06 \mathrm{~d}$ \\
\hline $\mathrm{SS}^{\mathrm{c}}$ & $40.58 \pm 0.61 b$ & $27.25 \pm 0.56 \mathrm{a}$ & $35.34 \pm 0.11 \mathrm{a}$ & $33.78 \pm 0.58 \mathrm{~d}$ & $6.14 \pm 0.07 b$ \\
\hline $\mathrm{WS}^{\mathrm{c}}$ & $35.69 \pm 0.54 \mathrm{e}$ & $25.23 \pm 0.66 b c$ & $32.59 \pm 0.39 b$ & $38.37 \pm 0.22 c$ & $5.83 \pm 0.04 c$ \\
\hline $\mathrm{RS}^{\mathrm{c}}$ & $33.03 \pm 0.04 \mathrm{~g}$ & $25.88 \pm 0.23 b$ & $30.31 \pm 0.26 c$ & $39.39 \pm 0.52 b$ & $5.16 \pm 0.07 \mathrm{e}$ \\
\hline $\mathrm{GS}^{\mathrm{c}}$ & $34.06 \pm 0.18 \mathrm{f}$ & $25.39 \pm 0.44 b c$ & $25.61 \pm 0.42 d$ & $45.28 \pm 0.87 \mathrm{a}$ & $6.46 \pm 0.03 \mathrm{a}$ \\
\hline$J^{c}$ & $38.86 \pm 0.16 c$ & $20.36 \pm 0.32 \mathrm{e}$ & $24.46 \pm 0.08 \mathrm{e}$ & $45.85 \pm 0.64 a$ & $5.63 \pm 0.06 \mathrm{~d}$ \\
\hline $\mathrm{ZS}^{\mathrm{c}}$ & $37.66 \pm 0.63 d$ & $24.71 \pm 0.21 \mathrm{c}$ & $25.35 \pm 0.47 \mathrm{~d}$ & $30.08 \pm 0.44 f$ & $5.84 \pm 0.06 c$ \\
\hline $\mathrm{CS}^{\mathrm{c}}$ & $25.04 \pm 0.72 h$ & $25.06 \pm 0.54 b c$ & $30.32 \pm 0.48 c$ & $39.54 \pm 0.43 b$ & $5.11 \pm 0.02 \mathrm{e}$ \\
\hline
\end{tabular}

${ }^{a}$ Each value is expressed as the mean of triplicate samples \pm SD; ${ }^{\circ}$ Means in the same row with different letters are significantly different by Duncan's multiple range test ( $\mathrm{p}<0.05$ );

${ }^{\circ} \mathrm{KS}$, SS, RS, WS, GS, JS, ZS and CS represented kedong Sufu, spontaneous Sufu, red Sufu, white Sufu, grey Sufu, jiang Sufu, zaofang Sufu, and cabbage Sufu, respectively. 

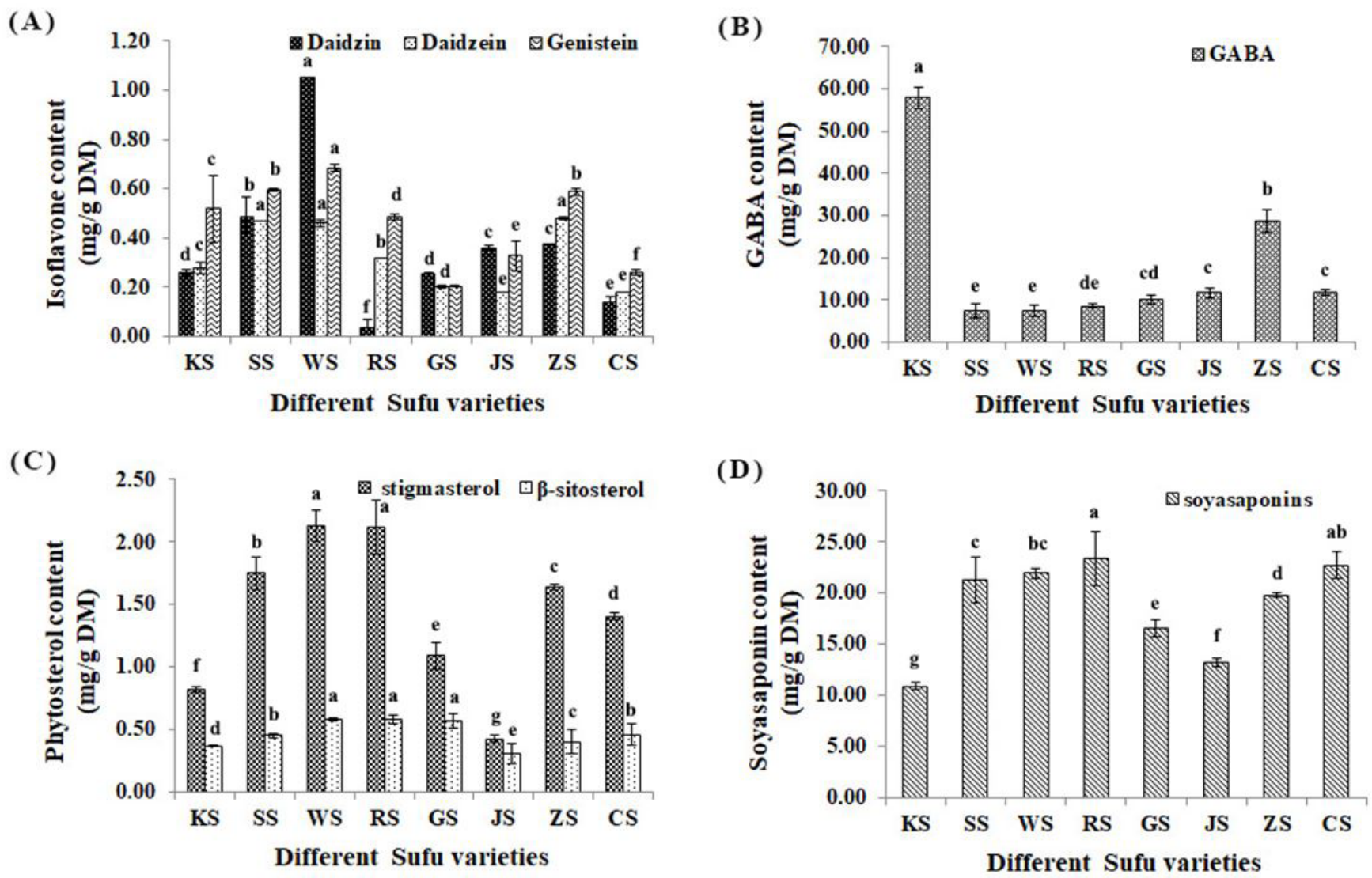

Figure 2. The contents of functional components including isoflavones (A), GABA (B), phytosterols (C) and soyasaponins (D) in different Sufu varieties. KS, SS, RS, WS, GS, JS, ZS and CS represented kedong Sufu, spontaneous Sufu, red Sufu, white Sufu, grey Sufu, jiang Sufu, zaofang Sufu, and cabbage Sufu, respectively; Each value is expressed as the mean of triplicate samples \pm SD; Means in the same row with different letters are significantly different by Duncan's multiple range test $(\mathrm{p}<0.05)$.

$(1.05 \mathrm{mg} / 100 \mathrm{~g} \mathrm{DM})$ and genistein $(0.68 \mathrm{mg} / 100 \mathrm{~g} \mathrm{DM})$. The lowest levels of daidzin, genistein and daidzein were $0.04 \mathrm{mg} / 100 \mathrm{~g} \mathrm{DM}$ in RS, $0.21 \mathrm{mg} / 100 \mathrm{~g} \mathrm{DM}$ in JS and $0.18 \mathrm{mg} / 100 \mathrm{~g} \mathrm{DM}$ in CS, respectively (Figure $2 \mathrm{~A}$ ). This might be related to differences in the raw materials, ripening time, manufacturing process and isoflavone extraction parameters. For instance, site and cultivar had significant influences on the daidzin contents of soybean cultivars. Daidzin contents of soybean cultivars grown in Northern was $35.2 \mathrm{mg} / 100 \mathrm{~g}$, which was higher than that in Southern China (27.6 mg/100 g) (Zhang et al., 2014).

The GABA levels are presented in Figure 2B, which showed that the contents of different Sufus were remarkably different. Among them, BFS (KS) reached up to $57.95 \mathrm{mg} / \mathrm{g} \mathrm{DM}$, which was approximately 8 times higher than that of NFS (SS) and MFS (WS). Soy protein is rich in glutamic acid, and fermentation is known to be an effective method for GABA enrichment, especially in strict anaerobic conditions. Sufu ripening is generally confined to an anaerobic environment, which could contribute to GABA accumulation. It is widely known that some bacteria, such as Lactobacillus brevis and Bacillus licheniformis, could accumulate GABA (Wu \& Shah, 2017; Zhao et al., 2013). The highest GABA contents in BFS might be caused by abundant GABA-producing bacteria, such as Bacillus.

Phytosterols are steroid compounds and vary in carbon side chains or double bonds. As the most commonly occurring phytosterols, $\beta$-sitosterol and stigmasterol are structurally and functionally analogous to cholesterol. The stigmasterol contents $(0.43-2.13 \mathrm{mg} / 100 \mathrm{~g} \mathrm{DM})$ were higher than $\beta$-Sitosterol $(0.31-0.59 \mathrm{mg} / 100 \mathrm{~g} \mathrm{DM})$ in all of the investigated Sufus. The stigmasterol content in WS $(2.13 \mathrm{mg} / 100 \mathrm{~g} \mathrm{DM})$ was the most abundant, which was similar to RS $(2.11 \mathrm{mg} / 100 \mathrm{~g} \mathrm{DM})$ (Figure 2C).

Soyasaponins are amphiphilic oleanane triterpenoid glycosides with polar sugar chains that are conjugated to a nonpolar pentacyclic ring. As shown in Figure 2D, the soyasaponin contents ranged from $10.89 \mathrm{mg} / 100 \mathrm{~g} \mathrm{DM}(\mathrm{KS})$ to $23.35 \mathrm{mg} / 100 \mathrm{~g}$ DM (RS). Compared to $0.1 \%$ to $0.5 \%$ in the whole soybean, the content of total soyasaponins in the seed hypocotyl fraction of soybeans ranged from $0.62 \%$ to $6.16 \%$. The soybean varieties had an important influence on the soyasaponin contents in Sufu. The soyasaponin concentration of medium-seed was slightly higher than those of large-seed and small-seed varieties (Sunlim et al., 2006). 


\subsection{Potential tasty fractions}

FAA profiles

As shown in Table 3, 17 kinds of FAAs were identified and the contents were obviously different from each other. Glu (4.88 $\pm 0.84-21.66 \pm 1.01 \mathrm{mg} / \mathrm{g} \mathrm{DM})$ was the most abundant, followed by Phe, Leu, Val and Asp. Among the various examined FAAs, Leu was the most abundantly detected in grey Sufu, whereas Glu was the most abundant in the other types of

Sufu (Han et al., 2004; Li et al., 2010; Ma et al., 2013). This was also consistent with soybeans, in which Glu was the major amino acid (Zarkadas et al., 2007). Kinema, known as a kind of traditional Bacillus-fermented soybeans, was found to include Glu, Phe and Leu as the major FAAs. For CS, the level of total free amino acid (TFAA) was the highest $(104.14 \pm 0.60 \mathrm{mg} / \mathrm{g} \mathrm{DM})$, and was approximately three times higher than that in JS $(30.80 \pm 3.01 \mathrm{mg} / \mathrm{g} \mathrm{DM})$. Both JS and CS were categorized as MFS, and moulds were the main strains in the culture phase. The significant difference indicated that both of fermentation time during Sufu preparation and protein content in the soybean had more important influences on the TFAA. The The essential amino acid (EAA) contents ranged from $15.23 \pm 1.68$ to $49.57 \pm 0.27 \mathrm{mg} / \mathrm{g} \mathrm{DM}$, which accounted for approximately $50 \%$ of TFAAs. The patterns of EAAs were comparable to those of eggs and milk proteins. Antioxidative amino acid (Tyr, Met, His, and Lys) contents, ranging from
$6.29 \pm 0.78$ to $13.86 \pm 1.61 \mathrm{mg} / \mathrm{g} \mathrm{DM}$, were about 5 times higher than those in soy sauce (Goh et al., 2017).

As one of the important quality indicators, taste perception is a high priority in food applications. Based on taste characteristics, FAAs can be grouped as monosodium glutamate-like (MSG-like), sweet, bitter and tasteless according to the report by Tseng et al. (2005). Compared to the sweet and tasteless groups, MSG-like and bitter were the major FAA groups (Figure 3 ). Similar to the

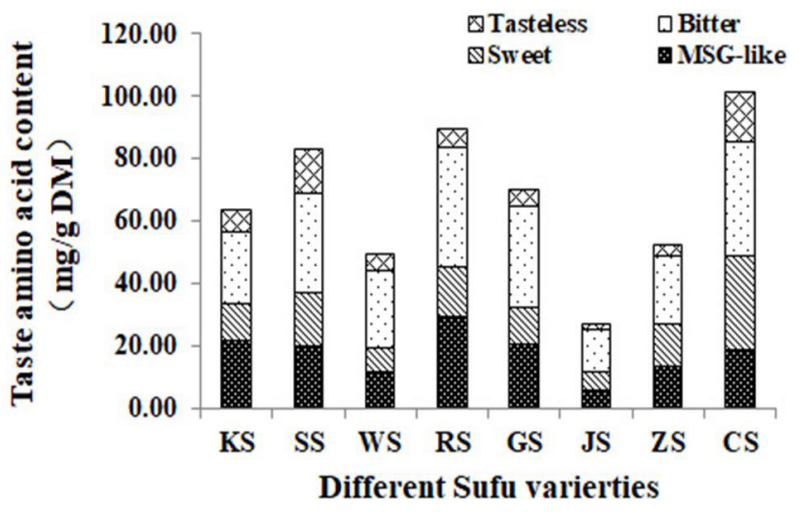

Figure 3. Taste characteristics of FAAs in different Sufu varieties. KS, SS, RS, WS, GS, JS, ZS and CS represented kedong Sufu, spontaneous Sufu, red Sufu, white Sufu, grey Sufu, jiang Sufu, zaofang Sufu, and cabbage Sufu, respectively.

Table 3. FAA profiles of different Sufu varieties ${ }^{\mathrm{a}}$.

\begin{tabular}{|c|c|c|c|c|c|c|c|c|c|}
\hline FAAs & $\mathrm{KS}^{\mathrm{e}}$ & $\mathrm{SS}^{\mathrm{e}}$ & $\mathrm{WS}^{\mathrm{e}}$ & $\mathrm{RS}^{\mathrm{e}}$ & $\mathrm{GS}^{\mathrm{e}}$ & $\mathrm{JS}^{\mathrm{e}}$ & $\mathrm{ZS}^{\mathrm{e}}$ & $\mathrm{CS}^{\mathrm{e}}$ & $\begin{array}{c}\text { Threshold } \\
\text { values }^{\mathrm{b}}\end{array}$ \\
\hline Asp & $5.64 \pm 0.69 b$ & $2.09 \pm 0.32 \mathrm{e}$ & $5.22 \pm 0.22 b c$ & $7.56 \pm 0.27 a$ & $3.79 \pm 0.55 \mathrm{~d}$ & $1.21 \pm 0.19 f$ & $4.85 \pm 0.30 c$ & $1.72 \pm 0.27 \mathrm{ef}$ & 1.00 \\
\hline Thr & $2.89 \pm 0.41 c$ & $0.60 \pm 0.21 \mathrm{e}$ & $2.51 \pm 0.50 \mathrm{~cd}$ & $4.31 \pm 0.33 b$ & $0.64 \pm 0.03 e$ & $1.92 \pm 0.52 \mathrm{~d}$ & $2.99 \pm 0.17 c$ & $5.13 \pm 0.53 a$ & 2.60 \\
\hline Ser & $3.56 \pm 0.44 b$ & $0.38 \pm 0.05 d$ & $<0.01$ & $3.75 \pm 0.31 b$ & $<0.01$ & $1.63 \pm 0.09 c$ & $3.79 \pm 0.13 b$ & $6.83 \pm 0.56 a$ & 1.50 \\
\hline Glu & $16.39 \pm 1.53 b$ & $17.88 \pm 0.88 b$ & $6.41 \pm 0.56 \mathrm{~d}$ & $21.66 \pm 1.01 \mathrm{a}$ & $16.96 \pm 0.77 b$ & $4.88 \pm 0.84 \mathrm{~d}$ & $8.81 \pm 0.77 c$ & $17.10 \pm 1.89 \mathrm{~b}$ & 0.30 \\
\hline Pro & $2.85 \pm 0.49 b$ & $<0.01$ & $<0.01$ & $<0.01$ & $<0.01$ & $<0.01$ & $<0.01$ & $5.36 \pm 0.55 a$ & 3.00 \\
\hline Gly & $1.90 \pm 0.28 \mathrm{~d}$ & $3.52 \pm 0.41 \mathrm{a}$ & $1.88 \pm 0.56 \mathrm{~d}$ & $2.85 \pm 0.06 \mathrm{~b}$ & $2.61 \pm 0.23 b c$ & $0.54 \pm 0.08 \mathrm{e}$ & $2.23 \pm 0.09 \mathrm{~cd}$ & $3.96 \pm 0.24 a$ & 1.30 \\
\hline Ala & $3.46 \pm 0.47 f$ & $12.76 \pm 0.39 b$ & $3.51 \pm 0.44 \mathrm{f}$ & $5.54 \pm 0.33 \mathrm{~d}$ & $8.30 \pm 0.62 c$ & $1.47 \pm 0.11 \mathrm{~g}$ & $4.41 \pm 0.12 \mathrm{e}$ & $14.32 \pm 0.79 a$ & 0.60 \\
\hline Cys & $<0.01$ & $8.90 \pm 0.24 a$ & $2.19 \pm 0.64 b$ & $<0.01$ & $2.31 \pm 0.68 b$ & $<0.01$ & $<0.01$ & $2.33 \pm 0.25 b$ & $\mathrm{ND}$ \\
\hline Val & $5.34 \pm 0.49 c$ & $6.65 \pm 0.21 b$ & $4.25 \pm 0.63 \mathrm{~d}$ & $7.96 \pm 0.34 a$ & $7.43 \pm 0.54 \mathrm{ab}$ & $2.36 \pm 0.33 e$ & $5.39 \pm 0.47 c$ & $7.93 \pm 0.61 a$ & 0.40 \\
\hline Met & $1.44 \pm 0.22 \mathrm{bcd}$ & $1.72 \pm 0.28 \mathrm{abc}$ & $1.61 \pm 0.13 \mathrm{abc}$ & $1.91 \pm 0.28 \mathrm{a}$ & $1.14 \pm 0.04 \mathrm{de}$ & $0.96 \pm 0.08 \mathrm{e}$ & $1.41 \pm 0.13 \mathrm{~cd}$ & $1.88 \pm 0.45 \mathrm{ab}$ & 0.90 \\
\hline Ile & $3.28 \pm 0.18 \mathrm{~d}$ & $5.60 \pm 0.29 c$ & $3.59 \pm 0.52 \mathrm{~d}$ & $6.18 \pm 0.82 b c$ & $6.95 \pm 0.58 \mathrm{ab}$ & $1.10 \pm 0.08 \mathrm{e}$ & $3.37 \pm 0.20 \mathrm{~d}$ & $7.14 \pm 0.75 a$ & 1.90 \\
\hline Leu & $5.64 \pm 0.55 e$ & $8.60 \pm 0.59 c$ & $6.94 \pm 0.36 \mathrm{~d}$ & $9.89 \pm 0.77 b$ & $9.96 \pm 0.27 b$ & $2.58 \pm 0.12 f$ & $5.31 \pm 0.18 \mathrm{e}$ & $11.04 \pm 0.63 a$ & 1.90 \\
\hline Tyr & $3.79 \pm 0.51 b$ & $3.93 \pm 0.38 \mathrm{ab}$ & $4.55 \pm 0.34 a$ & $3.61 \pm 0.50 b c$ & $2.47 \pm 0.24 d$ & $3.43 \pm 0.14 b c$ & $4.54 \pm 0.18 \mathrm{a}$ & $2.95 \pm 0.62 \mathrm{~cd}$ & $\mathrm{ND}$ \\
\hline Phe & $5.86 \pm 0.71 \mathrm{de}$ & $7.09 \pm 0.75 c$ & $6.61 \pm 0.16 \mathrm{~cd}$ & $9.56 \pm 0.15 a$ & $7.31 \pm 0.22 c$ & $3.52 \pm 0.43 f$ & $5.21 \pm 0.15 e$ & $8.17 \pm 0.51 b$ & 0.90 \\
\hline Lys & $4.20 \pm 0.41 c$ & $5.75 \pm 0.26 b$ & $3.10 \pm 0.34 \mathrm{~d}$ & $5.86 \pm 0.54 b$ & $2.68 \pm 0.50 \mathrm{~d}$ & $1.99 \pm 0.17 \mathrm{e}$ & $3.37 \pm 0.58 \mathrm{~d}$ & $8.28 \pm 0.07 a$ & 0.50 \\
\hline His & $1.06 \pm 0.12 c$ & $1.82 \pm 0.55 b$ & $1.91 \pm 0.61 b$ & $2.48 \pm 0.29 a$ & $<0.01$ & $0.80 \pm 0.11 c$ & $1.15 \pm 0.15 c$ & $<0.01$ & 0.20 \\
\hline Arg & $<0.01$ & $<0.01$ & $<0.01$ & $<0.01$ & $<0.01$ & $2.41 \pm 0.16 \mathrm{a}$ & $<0.01$ & $<0.01$ & 0.50 \\
\hline TFAA $^{c}$ & $67.30 \pm 0.96 \mathrm{e}$ & $87.29 \pm 1.41 c$ & $54.28 \pm 1.35 f$ & $93.12 \pm 2.22 b$ & $72.55 \pm 0.59 \mathrm{~d}$ & $30.80 \pm 3.01 \mathrm{~g}$ & $56.83 \pm 0.76 f$ & $104.14 \pm 0.60 a$ & \\
\hline $\mathrm{EAA}^{\mathrm{d}}$ & $29.71 \pm 0.49 \mathrm{~cd}$ & $37.83 \pm 1.06 \mathrm{~b}$ & $30.52 \pm 0.99 c$ & $48.15 \pm 1.88 \mathrm{a}$ & $36.11 \pm 1.64 b$ & $15.23 \pm 1.68 \mathrm{e}$ & $28.20 \pm 0.47 \mathrm{~d}$ & $49.57 \pm 0.27 \mathrm{a}$ & \\
\hline AFAA $^{\mathrm{f}}$ & $10.49 \pm 0.44 b$ & $13.22 \pm 0.71 \mathrm{a}$ & $11.17 \pm 0.74 b$ & $13.86 \pm 1.61 \mathrm{a}$ & $6.29 \pm 0.78 c$ & $7.18 \pm 0.22 c$ & $10.47 \pm 0.48 b$ & $13.11 \pm 1.14 a$ & \\
\hline EAA/TFAA ${ }^{g}$ & $44.15 \pm 0.10 \mathrm{e}$ & $43.33 \pm 0.51 \mathrm{e}$ & $56.22 \pm 0.43 a$ & $51.70 \pm 0.79 b$ & $49.77 \pm 1.85 c$ & $49.41 \pm 0.63 c$ & $49.63 \pm 1.49 c$ & $47.60 \pm 0.54 d$ & \\
\hline $\begin{array}{l}\text { AFAA/ } \\
\text { TFAA }^{\mathrm{g}}\end{array}$ & $15.60 \pm 0.88 \mathrm{~d}$ & $15.14 \pm 0.57 d$ & $20.57 \pm 0.85 b$ & $14.86 \pm 1.38 \mathrm{~d}$ & $8.67 \pm 1.00 f$ & $23.41 \pm 1.58 \mathrm{a}$ & $18.43 \pm 1.09 c$ & $12.59 \pm 1.03 \mathrm{e}$ & \\
\hline
\end{tabular}

${ }^{a}$ All the data are expressed in the unit of $\mathrm{mg} / \mathrm{g}$ DM. Each value is expressed as mean $\pm \mathrm{SD}(\mathrm{n}=3)$. Means with different letter( $\mathrm{s}$ ) within a row are significantly different ( $\left.\mathrm{p}<0.05\right)$; ${ }^{\mathrm{b}}$ Threshold value is expressed as $\mathrm{mg}(\mathrm{FAA}) / \mathrm{mL}$ (water); ' Total contents of FAAs; ${ }^{\mathrm{d} E s s e n t i a l}$ amino acids; ${ }^{\mathrm{K} S}$, SS, RS, WS, GS, JS, ZS and CS represented kedong Sufu, spontaneous Sufu, red Sufu, white Sufu, grey Sufu, jiang Sufu, zaofang Sufu, and cabbage Sufu, respectively; ${ }^{\mathrm{f} A n t i o x i d a t i v e ~ f r e e ~ a m i n o ~ a c i d s ; ~}{ }^{\mathrm{B}}$ EAA/TFAA and AFAA/TFAA are expressed in the unit of $\%$; ND = not detected. 
taste characteristics of douchiba (Qin \& Ding, 2007) and thua nao (Dajanta et al., 2011), bitter was also the most abundant taste group in Sufus. As a unique characteristic of these products, bitter taste may come from unbalanced proteolysis of alkaline-fermented soybean. Bitterness limits the acceptance and marketing of fermented food, while a limited level of bitterness may be desirable. Two of the so-called bitter amino acids Phe and Tyr, at subthreshold concentrations showed a significant umami-enhancing effect on the umami taste of $\mathrm{MSG} / \mathrm{NaCl}$ mixtures (Lioe et al., 2005).

As a basic taste typified by the Glu and Asp, MSG-like taste can impart a savory, brothy, rich or meaty taste sensation. There is a synergistic effect in the interaction between taste active amino acids. For instance, the umami taste was more intense than that of MSG or 5'-ribonucleotide alone, when Cys, His, Met, Pro and Val were added to the mixture of MSG and 5'-ribonucleotide (Zhao et al., 2016). In terms of the sweet taste, the quantities of sweet FAA, displayed in Figure 3, were relatively low. However, Gly and Ala could elicit a strong sweet taste. It is thought that the strong sweet taste elicited by these amino acids is due to the ability of these molecules to bind to the sweet substance receptors. It is noted that although tasteless amino acids are not taste active, they enhance the taste intensity of other compounds modulating the signal transduction from the taste receptors to the brain.

\section{Peptide profiles}

The peptide profiles of the low-molecular mass fractions are shown in Table 4 . The fraction with $\mathrm{MW}<300 \mathrm{Da}$, which mainly consisted of FAAs and small peptides with two or three amino acid residues, were the most abundant $(79.22 \% \pm 4.12 \%-95.24 \% \pm 2.93 \%)$ of the four peptide fractions. Higher proportion of low-molecular mass peptides in RS $(91.56 \% \pm 2.93 \%)$ and CS $(-95.24 \% \pm 2.93 \%)$ mainly ascribed to extensive proteolysis during the longer post- fermentation. Correspondingly, oligopeptide (500-1000 Da), medium-molecular (1000-2000 Da) and high-molecular peptide (2000-5000 Da) accounted for only a small fraction. In accordance with this result, the amount of fraction with $\mathrm{MW}<300 \mathrm{Da}$ in the low-molecular mass peptide fraction increased to $76.59 \%$ during the douchiba manufacture (Qin \& Ding, 2007). Similar phenomena were also described earlier in white Sufu fermentation (Cai et al., 2016). Peptides, eliciting specific taste characteristics, such as bitter, umami, sweet, sour, salty and astringent, received special attentions. The dipeptide Glu-Tyr has been related to the aged taste, and the dipeptides Val-Glu and Gly-Glu have been related to sour taste in dry-cured ham (Mora \& Toldrá,
2012). The sweet peptide, aspartame (L-Asp-L-Phe-OMe) has a sweet taste that is 180 times of sucrose. Most taste-active peptides had a low molecular mass. The abundant proteolytic tasty components (FAAs and low-molecular peptide) released during fermentation, played an important role in attractive taste and odor and nutritive value. Therefore, special attentions should be paid to the proteolytic tasty components derived from proteolysis and their interactions in further study to develop tastier and less bitter Sufus.

\section{Complex taste impression based on electronic tongue analysis}

Taste determines food selection, intake, absorption and digestion. An electronic tongue was used to evaluate the complex taste impression, and the results are shown in Figure 4. The bitterness intensity was the highest, followed by saltiness. Sufu was roughly comparable in astringency and umami intensity, and showed negative scores in sourness. There was slight difference for all tastes except sourness (Figure 4A). However, the sensory properties in practical consumptions had a characteristic taste profile, in which saltiness was predominant, followed by intense umami and accompanied with slight bitterness, sourness and astringency (Qin \& Ding, 2007). The phenomenon may be attributed to the taste-substance interactions, such as synergistic and suppression effects (Kobayashi et al., 2010). For instance, bitterness, derived from bitter amino acids and hydrophobic bitter peptide fractions, may be attributed to the diminishing or masking effect of saltiness, umami taste, sourness and sweetness. Umami taste, which was more intense than expected, was possibly the result of the synergistic action of relatively abundant low molecular mass peptide fractions and MSG-like taste amino acids, as mentioned above (Kim \& Lee, 2003). The final taste was also influenced by the threshold value of taste-active compounds. If the levels of some FAAs in natural foods are lower than their threshold values, they may contributed little to the taste. However, they may have an important role in improving the flavor of the food because of the synergistic effect.

PCA was used to demonstrate sample patterns, grouping, similarities and differences in the data sets of electronic tongue (Knysak \& Knysak, 2017). As shown in Figure 4B, PC1 and PC2 accounted for $56.8 \%$ and $24.0 \%$ of the total variance, respectively. The first 2 principal components retained $80.8 \%$ of the original data information. The taste characteristics of KS and SS were largely different from RS, WS, GS, JS, CS and ZS when projected on PC1. When the eight Sufu samples were divided into three groups (BFS, NFS and MFS), PC1 clearly separated the three groups without any overlap. However, the individual PCA biplots

Table 4. The molecular mass distribution of the low-molecular mass peptide fractions $\mathrm{s}^{\mathrm{a}, \mathrm{b}}$.

\begin{tabular}{ccccccccc}
\hline $\mathrm{MW} / \mathrm{Da}$ & $\mathrm{KS}^{\mathrm{c}}$ & $\mathrm{SS}^{\mathrm{c}}$ & $\mathrm{WS}^{\mathrm{c}}$ & $\mathrm{RS}^{\mathrm{c}}$ & $\mathrm{GS}^{\mathrm{c}}$ & $\mathrm{JS}^{\mathrm{c}}$ & $\mathrm{ZS}^{\mathrm{c}}$ & $\mathrm{CS}^{\mathrm{c}}$ \\
\hline$<300$ & $87.67 \pm 5.03 \mathrm{bc}$ & $84.80 \pm 4.94 \mathrm{~cd}$ & $79.88 \pm 2.64 \mathrm{~d}$ & $91.56 \pm 1.29 \mathrm{ab}$ & $95.24 \pm 2.93 \mathrm{a}$ & $79.22 \pm 4.12 \mathrm{~d}$ & $87.51 \pm 3.12 \mathrm{bc}$ & $92.91 \pm 1.95 \mathrm{ab}$ \\
$500-1000$ & $4.33 \pm 0.27 \mathrm{e}$ & $7.09 \pm 0.35 \mathrm{c}$ & $10.04 \pm 0.13 \mathrm{a}$ & $4.14 \pm 0.13 \mathrm{ef}$ & $1.60 \pm 0.25 \mathrm{~g}$ & $9.19 \pm 0.14 \mathrm{~b}$ & $6.01 \pm 0.82 \mathrm{~d}$ & $3.69 \pm 0.07 \mathrm{f}$ \\
$1000-2000$ & $3.35 \pm 0.35 \mathrm{bc}$ & $3.98 \pm 0.28 \mathrm{~b}$ & $4.67 \pm 0.43 \mathrm{a}$ & $1.70 \pm 0.24 \mathrm{~d}$ & $1.05 \pm 0.21 \mathrm{e}$ & $5.24 \pm 0.02 \mathrm{a}$ & $2.98 \pm 0.24 \mathrm{c}$ & $1.81 \pm 0.74 \mathrm{~d}$ \\
$2000-5000$ & $4.65 \pm 0.46 \mathrm{c}$ & $4.11 \pm 0.46 \mathrm{c}$ & $5.40 \pm 0.13 \mathrm{~b}$ & $2.60 \pm 0.37 \mathrm{e}$ & $0.14 \pm 0.06 \mathrm{~g}$ & $6.36 \pm 0.52 \mathrm{a}$ & $3.48 \pm 0.34 \mathrm{~d}$ & $1.58 \pm 0.20 \mathrm{f}$ \\
\hline
\end{tabular}

${ }^{a}$ Each value is expressed as the mean of triplicate samples $\pm \mathrm{SD}$; ${ }^{\mathrm{b}}$ Means in the same row with different letters are significantly different by Duncan's multiple range test ( $\mathrm{p}<0.05$ );

${ }^{c} \mathrm{KS}$, SS, RS, WS, GS, JS, ZS and CS represented kedong Sufu, spontaneous Sufu, red Sufu, white Sufu, grey Sufu, jiang Sufu, zaofang Sufu, and cabbage Sufu, respectively. 

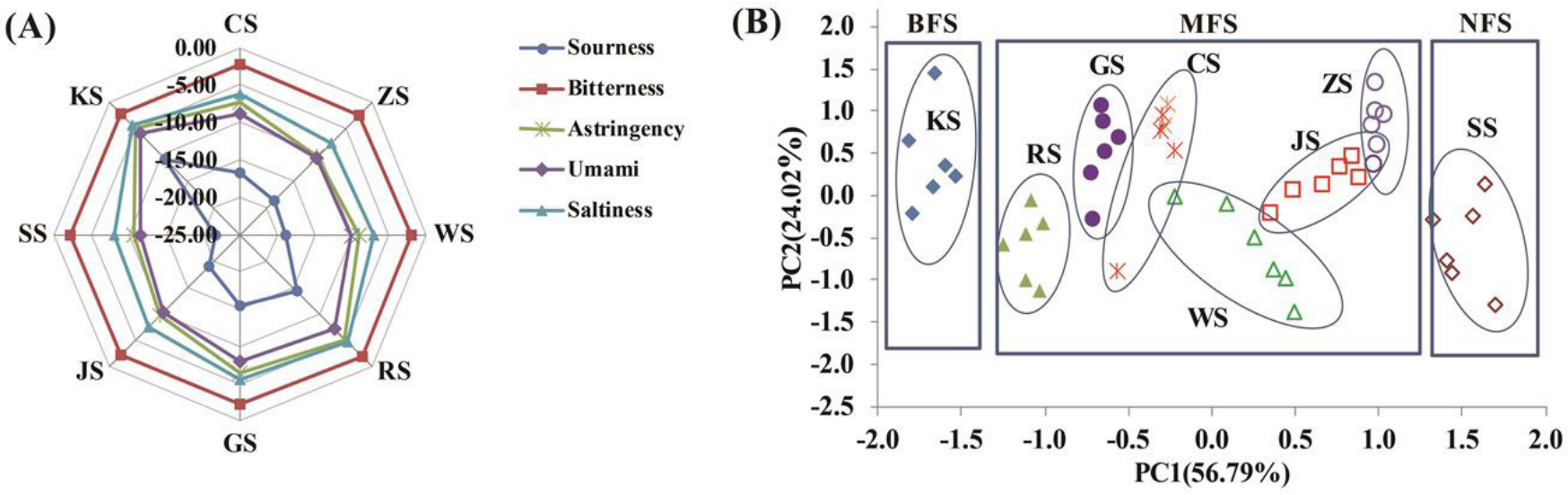

Figure 4. Complex taste impression of different Sufu varieties by electronic tongue (A) Spider plot for the sensory score; (B) PCA score plots; n=6. KS, SS, RS, WS, GS, JS, ZS and CS represented kedong Sufu, spontaneous Sufu, red Sufu, white Sufu, grey Sufu, jiang Sufu, zaofang Sufu, and cabbage Sufu, respectively.

showed that there was overlap among all Sufu samples when projected on PC2. The above analysis indicated that, to some extent, MFS, NFS and BFS can be distinguished according to the electronic tongue results.

\section{Conclusions}

Significant differences were found in the nutritional, functional and tasty components of three categories of Sufu, divided by strains in the culture phase. However, with the exception of taste impression based on electronic tongue, different Sufu categories cannot well be distinguished according to the nutritional and functional alone. It is speculated that the quality differences among the various categories of Sufu are determined by new microbes from dressing mixtures and air in the post-ripening period rather than the strains in the culture phase. Likewise, volatile flavor components may be catabolized by microbes in the post-ripening period. Therefore, intimate knowledge of the interactions between quality (nutritional, functional, tasty and volatile flavor components) and microbes in the future will help people gain a deeper understanding of Chinese Sufus and enable development of novel fermentation strategies to improve Sufu quality.

\section{Acknowledgements}

This research was funded by the Natural Science Foundation of China (31760458), Science and Technology Program of Guizhou Province ([2017]5788) and Science and Technology Major Project of Guizhou Province ([2014] 6023).

\section{References}

Association of Official Analytical Chemists - AOAC. (2000). Official methods of the association of agricultural chemists (17th ed.). Washington: AOAC.

Cai, R. C., Li, L., Yang, M., Cheung, H. Y., \& Fu, L. (2016). Changes in bioactive compounds and their relationship to antioxidant activity in white sufu during manufacturing. International Journal of Food
Science \& Technology, 51(7), 1721-1730. http://dx.doi.org/10.1111/ ijfs. 13149 .

Cetó, X., González-Calabuig, A., Crespo, N., Pérez, S., Capdevila, J., Puig-Pujol, A., \& Valle, M. D. (2017). Electronic tongues to assess wine sensory descriptors. Talanta, 162, 218-224. http://dx.doi. org/10.1016/j.talanta.2016.09.055. PMid:27837821.

Cheng, K. C., Wu, J. Y., Lin, J. T., \& Liu, W. H. (2013). Enhancements of isoflavone aglycones, total phenolic content, and antioxidant activity of black soybean by solid-state fermentation with Rhizopus spp. European Food Research and Technology, 236(6), 1107-1113. http://dx.doi.org/10.1007/s00217-013-1936-7.

Cheng, Y.-Q., Zhu, Y.-P., Hu, Q., Li, L.-T., Saito, M., Zhang, S.-X., \& Yin, L.-J. (2011). Production of sufu, a traditional Chinese fermented soybean food, by fermentation with Mucor flavus at low temperature. International Journal of Food Properties, 14(3), 629-639. http://dx.doi. org/10.1080/10942910903312486.

Cusack, L. K., Fernandez, M. L., \& Volek, J. S. (2013). The food matrix and sterol characteristics affect the plasma cholesterol lowering of phytosterol/phytostanol. Advances in Nutrition, 4(6), 633-643. http:// dx.doi.org/10.3945/an.113.004507. PMid:24228192.

Dajanta, K., Apichartsrangkoon, A., Chukeatirote, E., \& Frazier, R. A. (2011). Free-amino acid profiles of thua nao, a Thai fermented soybean. Food Chemistry, 125(2), 342-347. http://dx.doi.org/10.1016/j. foodchem.2010.09.002.

Dong, W., Zhao, J., Hu, R., Dong, Y., \& Tan, L. (2017). Differentiation of Chinese robusta coffees according to species, using a combined electronic nose and tongue, with the aid of chemometrics. Food Chemistry, 229, 743-751. http://dx.doi.org/10.1016/j.foodchem.2017.02.149. PMid:28372239.

Goh, K. M., Lai, O. M., Abas, F., \& Tan, C. P. (2017). Effects of sonication on the extraction of free-amino acids from moromi and application to the laboratory scale rapid fermentation of soy sauce. Food Chemistry, 215, 200-208. http://dx.doi.org/10.1016/j.foodchem.2016.07.146. PMid:27542468.

Gomaa, E. Z., \& Rushdy, A. A. (2014). Improvement of Lactobacillus brevis NM101-1 grown on sugarcane molasses for mannitol, lactic and acetic acid production. Annals of Microbiology, 64(3), 983-990. http://dx.doi.org/10.1007/s13213-013-0733-7.

Han, B.Z., Beumer, R. R., Rombouts, F. M., \& Nout, M. J. R. (2001a). Microbiological safety and quality of commercial sufu-a Chinese 
fermented soybean food. Food Control, 12(8), 541-547. http://dx.doi. org/10.1016/S0956-7135(01)00064-0.

Han, B.Z., Rombouts, F. M., \& Nout, M. J. R. (2001b). A Chinese fermented soybean food. International Journal of Food Microbiology, 65(1-2), 1-10. http://dx.doi.org/10.1016/S0168-1605(00)00523-7. PMid:11322691.

Han, B.Z., Rombouts, F. M., \& Nout, M. J. R. (2004). Amino acid profiles of sufu, a Chinese fermented soybean food. Journal of Food Composition and Analysis, 17(6), 689-698. http://dx.doi.org/10.1016/j. jfca.2003.09.012.

Herranz, B., De la Hoz, L., Hierro, E., Fernández, M., \& Ordóñez, J. A. (2005). Improvement of the sensory properties of dry-fermented sausages by the addition of free amino acids. Food Chemistry, 91 (4), 673-682. http://dx.doi.org/10.1016/j.foodchem.2004.06.040.

Ishimoto, M., Rahman, S. M., Hanafy, M. S., Khalafalla, M. M., Elshemy, H. A., Nakamoto, Y., Kita, Y., Takanashi, K., Matsuda, F., Murano, Y., Funabashi, T., Miyagawa, H., \& Wakasa, K. (2010). Evaluation of amino acid content and nutritional quality of transgenic soybean seeds with high-level tryptophan accumulation. Molecular Breeding, 25(2), 313-326. http://dx.doi.org/10.1007/s11032-009-9334-3.

Jianming, W., Qiuqian, L., Yiyun, W., \& Xi, C. (2013). Research on soybean curd coagulated by lactic acid bacteria. SpringerPlus, 2(1), 250-260. http://dx.doi.org/10.1186/2193-1801-2-250. PMid:23888263.

Kang, B. S., Lee, J. E., \& Park, H. J. (2014). Electronic tongue-based discrimination of Korean rice wines (makgeolli) including prediction of sensory evaluation and instrumental measurements. Food Chemistry, 151(151), 317-323. http://dx.doi.org/10.1016/j. foodchem.2013.11.084. PMid:24423539.

Kim, S. H., \& Lee, K. A. (2003). Evaluation of taste compounds in water-soluble extract of a doenjang (soybean paste). Food Chemistry, 83(3), 339-342. http://dx.doi.org/10.1016/S0308-8146(03)00092-X.

Knysak, D., \& Knysak, D. (2017). Volatile compounds profiles in unroasted Coffea arabica and Coffea canephora beans from different countries. Food Science and Technology, 37(3), 444-448. http://dx.doi. org/10.1590/1678-457x.19216.

Kobayashi, Y., Habara, M., Ikezazki, H., Chen, R., Naito, Y., \& Toko, K. (2010). Advanced taste sensors based on artificial lipids with global selectivity to basic taste qualities and high correlation to sensory scores. Sensors, 10(4), 3411-3443. http://dx.doi.org/10.3390/ s100403411. PMid:22319306.

Kucuk, O. (2017). Soy foods, isoflavones, and breast cancer. Cancer, 123(11), 1901-1903. http://dx.doi.org/10.1002/cncr.30614. PMid:28263364.

Li, Y., Yu, R., \& Chou, C. (2010). Some biochemical and physical changes during the preparation of the enzyme-ripening sufu, a fermented product of soybean curd. Journal of Agricultural and Food Chemistry, 58(8), 4888-4893. http://dx.doi.org/10.1021/jf904600a. PMid:20218723.

Lioe, H. N., Apriyantono, A., Takara, K., Wada, K., \& Yasuda, M. (2005). Umami taste enhancement of MSG/NaCl mixtures by Subthreshold L-a-aromatic amino acids. Journal of Food Science, 70(7), s401-s405. http://dx.doi.org/10.1111/j.1365-2621.2005.tb11483.x.

Liu, J., Chang, S. K., \& Wiesenborn, D. (2005). Antioxidant properties of soybean isoflavone extract and tofu in vitro and in vivo. Journal of Agricultural and Food Chemistry, 53(6), 2333-2340. http://dx.doi. org/10.1021/jf048552e. PMid:15769177.

Liu, T., Li, B., Zhou, Y., Chen, J., \& Tu, H. (2015). HPLC determination of $\gamma$-aminobutyric acid in Chinese rice wine using pre-column derivatization. Journal of the Institute of Brewing, 121(1), 163-166. http://dx.doi.org/10.1002/jib.196.
Lou, D., Li, Y., Yan, G., Bu, J., \& Wang, H. (2016). Soy consumption with risk of coronary heart disease and stroke: a meta-analysis of observational studies. Neuroepidemiology, 46(4), 242-252. http:// dx.doi.org/10.1159/000444324. PMid:26974464.

Ma, Y., Wang, J., Cheng, Y., Yin, L., \& Li, L. (2013). Some biochemical and physical changes during manufacturing of grey sufu, a traditional Chinese fermented soybean curd. International Journal of Food Engineering, 9(1). http://dx.doi.org/10.1515/ijfe-2012-0204.

Ma, Y., Wang, J., Cheng, Y., Yin, L., Liu, X., \& Li, L. (2014). Selected quality properties and angiotensin I-converting enzyme inhibitory activity of low-salt sufu, a new type of Chinese fermented tofu. International Journal of Food Properties, 17(9), 2025-2038. http:// dx.doi.org/10.1080/10942912.2013.780253.

Marx, Í. M. G., Rodrigues, N., Dias, L. G., Veloso, A. C. A., Pereira, J. A., Drunkler, D. A., \& Peres, A. M. (2017). Quantification of table olives' acid, bitter and salty tastes using potentiometric electronic tongue fingerprints. Lebensmittel-Wissenschaft + Technologie, 79, 394-401. http://dx.doi.org/10.1016/j.lwt.2017.01.060.

Mora, L., \& Toldrá, F. (2012). Proteomic identification of small (2000 Da) myoglobin peptides generated in dry-cured ham. Food Technology and Biotechnology, 50(3), 343-349.

Qin, L., \& Ding, X. (2007). Evolution of proteolytic tasty components during preparation of Douchiba, a traditional Chinese soy-fermented appetizer. Food Technology and Biotechnology, 45(1), 85-90.

Sunlim, K., Berhow, M. A., Jungtae, K., Illmin, C., Chi, H. Y., Song, J., Namkyu, P., \& Jongrok, S. (2006). Composition and content of soyasaponins and their interaction with chemical components in different seed-size soybeans. Hangug Jagmul Haghoeji, 51(4), 340-347.

Tang, T., Qian, K., Shi, T., Wang, F., Li, J., Cao, Y., \& Hu, Q. (2011). Monitoring the contents of biogenic amines in sufu by HPLC with SPE and pre-column derivatization. Food Control, 22(8), 1203-1208. http://dx.doi.org/10.1016/j.foodcont.2011.01.018.

Thammarongtham, C., Turner, G., Moir, A. J., Tanticharoen, M., \& Cheevadhanarak, S. (2001). A new class of glutaminase from Aspergillus oryzae. Journal of Molecular Microbiology and Biotechnology, 3(4), 611-617. http://dx.doi.org/10.1016/j.foodcont.2011.01.018. PMid:11545278.

Tsai, Y. H., Chang, S. C., \& Kung, H. F. (2007). Histamine contents and histamine-forming bacteria in natto products in Taiwan. Food Control, 18(9), 1026-1030. http://dx.doi.org/10.1016/j.foodcont.2006.06.007.

Tseng, Y. H., Lee, Y. L., Li, R. C., \& Mau, J. L. (2005). Non-volatile flavour components of Ganoderma tsugae. Food Chemistry, 90(3), 409-415. http://dx.doi.org/10.1016/j.foodchem.2004.03.054.

Watanabe, H., Kashimoto, N., Kajimura, J., \& Kamiya, K. (2006). A miso (Japanese soybean paste) diet conferred greater protection against hypertension than a sodium chloride diet in Dahl saltsensitive rats. Hypertension Research Official Journal of the Japanese Society of Hypertension, 29(9), 731-738. http://dx.doi.org/10.1291/ hypres.29.731. PMid:17249529.

Wilcox, J., Haghpanah, R., Rupp, E. C., He, J., \& Lee, K. (2012). Comparative study of chemical composition and texture profile analysis between camembert cheese and Chinese sufu. Biotechnology Frontier, 1(1), 1-8.

Wu, Q., \& Shah, N. P. (2017). High $\gamma$-aminobutyric acid production from lactic acid bacteria: emphasis on Lactobacillus brevis as a functional dairy starter. Critical Reviews in Food Science and Nutrition, 57(17), 3661-3672. http://dx.doi.org/10.1080/10408398.2016.1147 418. PMid:26980301.

Xia, X., Li, G., Zheng, J., Ran, C., \& Kan, J. (2014). Biochemical, textural and microstructural changes in whole-soya bean cotyledon 
sufu during fermentation. International Journal of Food Science \& Technology, 49(8), 1834-1841. http://dx.doi.org/10.1111/ijfs.12492.

Yoon, Y. E., Kuppusamy, S., Cho, K. M., Kim, P. J., Kwack, Y. B., \& Lee, Y. B. (2017). Influence of cold stress on contents of soluble sugars, vitamin $\mathrm{C}$ and free amino acids including gamma-aminobutyric acid (GABA) in spinach (Spinacia oleracea). Food Chemistry, 215, 185-192. http://dx.doi.org/10.1016/j.foodchem.2016.07.167. PMid:27542466.

Zarkadas, C. G., Gagnon, C., Gleddie, S., Khanizadeh, S., Cober, E. R., \& Guillemette, R. J. D. (2007). Assessment of the protein quality of fourteen soybean [Glycine max (L.) Merr.] cultivars using amino acid analysis and two-dimensional electrophoresis. Food Research International, 40(1), 129-146. http://dx.doi.org/10.1016/j.foodres.2006.08.006.

Zhang, J., Ge, Y., Han, F., Li, B., Yan, S., Sun, J., \& Wang, L. (2014). Isoflavone content of soybean cultivars from maturity group 0 to
VI grown in Northern and Southern China. Journal of the American Oil Chemists' Society, 91(6), 1019-1028. http://dx.doi.org/10.1007/ s11746-014-2440-3. PMid:24882872.

Zhao, C. J., Schieber, A., \& Gänzle, M. G. (2016). Formation of taste-active amino acids, amino acid derivatives and peptides in food fermentations: a review. Food Research International, 89(Pt 1), 39-47. http://dx.doi.org/10.1016/j.foodres.2016.08.042. PMid:28460929.

Zhao, C., Zhang, Y., Wei, X., Hu, Z., Zhu, F., Xu, L., Luo, M., \& Liu, H. (2013). Production of ultra-high molecular weight poly- $\gamma$-glutamic acid with bacillus licheniformis P-104 and characterization of its flocculation properties. Applied Biochemistry and Biotechnology, 170(3), 562-572. http://dx.doi.org/10.1007/s12010-013-0214-2. PMid:23553109. 